DOI: $10.31866 / 2410-1915.21 .2020 .208237$

UDC 002.2:655.4/.5(100)

\title{
THE INTERNATIONAL ACTIVITY OF THE UKRAINIAN BOOK PUBLISHING INDUSTRY
}

\author{
Olena Karakoz
}

PhD in History, Associate Professor, ORCID: 0000-0002-7772-1530,karakoc@ukr.net, Kyiv National University of Culture and Arts, 36, Ye. Konovaltsia St., Kyiv, 01133, Ukraine

\section{For citations:}

Karakoz, O. (2020). The International Activity of the Ukrainian Book Publishing Industry. Culture and Arts in the Modern World, 21, 69-80. https://doi.org/10.31866/2410-1915.21.2020.208237.

The purpose of this article is to analyse the programmes of the international cooperation in the book publishing industry and to identify promising directions in the development of the Ukrainian book industry in the process of such cooperation. The research methodology is based on the use of comparative and historical, statistical methods that have provided comprehensive information in the field of international cooperation of Ukrainian publishing as of an activity that is very important for the cultural and intellectual development of the society. Bibliographic methods - functional, analytical and thematic, structural and typological - helped to determine the forms and methods to expand cooperation in the field of book publishing and at the same time define development prospects of the domestic book publishing, distribution and usage.

The scientific novelty lies in the fact that current international communication programmes in the field of publishing industry have been comprehensively examined for the first time. The field of international cooperation in the book publishing industry has been analysed as a complex systematic entity that performs its functions in various aspects and at different levels. Therefore, book publishing as a means of dissemination of national culture is at the same time a determining factor of progress of the world book industry and a phenomenon of international culture. An international interaction of cultures is needed for the development of each individual national culture, for the emergence of new resources and motivation for improvement. Thus, the necessity of international book publishing contacts depends on the objective needs.

Conclusions. It is shown that the international cooperation in the field of book publishing is aimed at the enhancing of the international cooperation of Ukraine with other countries; contributes to the strengthening of the international image of Ukraine; serves as a statement of common to all values; promotes the development of the national book industry; attracts Ukrainians to the world's spiritual and social values, technological achievements; ensures a direct and proper exchange of cultural, intellectual and material values.

The study identifies the main directions of international cooperation, including Ukraine's participation in the international book fairs, exhibitions; publishers' participation in the international programmes; intense activity in the field of literature translation, etc. Thus, the 
strategic goal and priorities of the international cooperation of Ukraine in book publishing industry has been defined: firstly, to increase the level of the national book publishing; secondly, the use of world achievements in domestic practice; thirdly, the promotion of the Ukrainian book publishing in the world.

Keywords: international cooperation; book publishing; culture; the Ukrainian book.

\section{Introduction}

At the present stage the Ukrainian society faces not only local but also global challenges. One of these is the global cultural revolution, which caused the shift to the digital culture. International relations in the field of culture, science and education have always been the most receptive to the new realities of the world and regional geopolitical situation. Book publishing industry, integrating the spiritual and material production, is potentially one of the most effective and flexible tools for international communication: from the episodic humanitarian contacts of book publishers with book distributors to multi-sector long-lasting cooperation that pays significant political, economic and socio-cultural dividends to all participating countries. Today, international cooperation in the book industry is a system of activity that is essential for the development of domestic book publishing, book distribution and book use for the full cultural and intellectual development of the society in general. And the way of appearance of the Ukrainian book publishing in the international scene, considering the use of international experience in the national practice, which has its peculiarities, is relevant and may become a significant factor in the progressive development of the book publishing industry of Ukraine.

The issues of the Ukrainian book publishing under market conditions and the possibility of using the foreign experience to solve them; the prospects for the cooperation for the Ukrainian book and positive developments in this area; the problems of state regulation of the book publishing development in Ukraine have been considered by many experts in publishing.

However, the diversity of directions, forms and methods of expanding cooperation in the field of book business determines the need for the future comprehensive study of the problem, involvement of scientific research that will provide scientific material for solving not only international partnership issues, but the problems of effective development of the Ukrainian book publishing.

\section{Purpose of the article}

The purpose of the article is to analyse the program of international cooperation in the field of book publishing and to identify prospective directions for the development of the Ukrainian book publishing industry in the process of such cooperation.

The research methodology is based on the use of comparative and historical, statistical methods that have provided comprehensive information in the field of international cooperation of Ukrainian publishing as of an activity that is very important for the cultural and intellectual development of the society. 
Bibliographic methods - functional, analytical and thematic, structural and typological - helped to determine the forms and methods to expand cooperation in the field of book publishing and at the same time define the development prospects of the domestic book publishing, distribution and usage.

The scientific novelty lies in the fact that current international communication programmes in the field of publishing industry has been comprehensively examined for the first time. The field of international cooperation in the book publishing industry has been analysed as a complex systematic entity that performs its functions in various aspects and at different levels.

\section{Main research material}

An important part of the humanity's cultural heritage is reading. That ability is a set of skills that are acquired in the process of education. The art of reading has been formed for centuries and has become a tradition. Today, we observe a shift to simple consumption of information. Thus, with the appearance of digital technologies, the culture of traditional reading is constantly changing in what is a sign of significant metamorphoses that occur with a man and society and need further studying. Though, it is known that the level of the culture of a country depends directly on the level of informational culture, the culture of reading (including a love for a book, interest in reading, comprehension and understanding of what one reads) and education of the individual citizen and the nation as a whole. The concept of book culture has traditionally been used to describe events and processes associated with the role of the book in the development of culture, achievements of book printing industry, different aspects of book existence in the society. In the framework of traditional book culture, the book as a universal component of culture, a symbol of human spiritual and material resources, a source of knowledge and progress, the most important means and subject of communication remains an invariable object of research in the field of book science (Antonyk, 2019). "It is noteworthy that the relations between the state and the book industry under the condition of market reform are greatly transformed, there is a transition of publishing houses and enterprises of the industry for self-sufficiency and self-financing, new forms of ownership appear and prices for publishing products are liberalized, etc. Recently, it has been postulated that in order to deal with the self-isolation of the Ukrainian book publishing in the system of world information flows, make it possible for the book and reading to regain their inherent function of the most influential factors in the formation of the best qualities of the human personality, it is necessary to determine the book publishing industry of Ukraine as a national strategic priority" (Demuz, 2018). Thus, the relations between the state and book publishing at the legislative level are regulated by the Law of Ukraine "On State Support of Book Publishing in Ukraine" of 2003 (Verkhovna Rada Ukrainy, 2003).

The book sphere is a specific unit both in the world and domestic market since the product is an intellectual property of the author, the successful realisation of which depends first of all on its perception by the reader. Publishers 
are working hard to provide an effective advertising campaign even before the release of a new edition in order to create high demand on the book resulting in rapid realisation of an edition, its reprint, the sale of copyright to partner countries and the increase in profit (Horobets, 2018).

International book exhibitions and fairs help to make successful presentation of the products and intellectual property in the world market. They are primarily intended to advertise and promote books and other publishing products as well as establish and develop international cooperation and cultural contacts between countries. At the same time, the role and importance of international book fairs and exhibitions are strengthened, the intensification of the process of integration in the book industry became one of the reasons for it: book markets of certain countries cross the national borders and acquire the international features. Being a trading platform for specialists, the functions performed by international book fairs, exhibitions in the context of globalization, unstable political situation in the world and other external and internal factors are being changed and transformed.

Publishers and other businesses of this industry, in its turn, use exhibitions as platforms for the demonstration of brand, promoting their authors, products and services, popularisation of book and reading. In the professional environment international exhibitions and fairs are considered, not without reason, as important events in the world book industry, which bring together thousands of professionals: publishers, polygraphic workers, authors, literary agents, book distributors, librarians, representatives of professional associations and other book related businesses.

Thus, in 2017 the Ukrainian book was presented in the Middle East for the first time. Beirut International Arab Book Fair took place in Beirut (Lebanon), where Ukraine was represented by the collective exhibition stand of "The Old Lion Publishing House" (Oksana Zobro), Book Arsenal (Oksana Khmelovska), "Anetta Antonenko Publishing House" (Anetta Antonenko), "Nora-Druk Publishers" (Eleonora Simonova), "Nika-Centre" Publishing House (Volodymyr Samoilenko). The exhibition not only helped to establish new professional contacts, to introduce the Ukrainian book to the local publishers and readers, but also agree on Ukraine's participation at the book fair in Abu Dhabi (UAE) (Vydavnytstvo Staroho Leva, 2017).

Abu Dhabi International Book Fair (ADIBF) was held from April 25 - May 1, 2018, where the Ukrainian exhibition stand was presented. The delegation was led by the writer, publisher and scholar Maryna Hrymych. The delegation included the representatives of "Duliby", "Nora-Druk", "Elvik", "Ranok" and "Anetta Antonenko Publishing House". The main event of the Ukrainian programme at the fair was the presentation of the bilingual Ukrainian-Arabic Ivan Franko's collection of works "Faded Leaves". The exhibition for the Ukrainian book society resulted in the acquisition by the Dubai Public Library of the Arabic translations of the works by Ivan Franko, Lesia Ukrainka, Ahatanhel Krymskyi, art albums and English translations of books by contemporary Ukrainian authors in order to replenish the funds of all seven emirates. It also should be noted that during the fair, the representatives of the Ukrainian book publishing 
industry were able to conduct substantial negotiations with publishers from Syria, Lebanon, the UAE, Egypt (with almost thirty responsible persons altogether) about the future cooperation. The important step was the establishment of contact with a potential partner in the exhibition activity - book fair in New Delhi (India) (Kravchenko, 2018a).

The year 2018 also marked the Ukrainian debut at the annual Sharjah International Book Fair (SIBF) (UAE). One of the most important events of this exhibition is the International Publishers Conference. For the first time the conference was attended by two representatives from Ukraine - Eleonora Simonova ("Nora-Druk Publishers") and Ivan Fedechko ("The Old Lion Publishing House"). The participation of the Ukrainian publishers in the conferences, exhibitions in the Arab regions and individual negotiations with colleagues resulted in the signing of 21 letters of intent: 17 - on translation from Ukrainian and 4 - on translation from Arabic (Kravchenko, 2018b).

In order to present the national exhibition stand, Ukrainian publishers have planned to participate in six significant international book exhibitions (Vilnius, London, Paris, Frankfurt, Warsaw, and Bologna Book Fairs) and in Ukraine - the International Book Arsenal Festival (Kyiv), Forum of Publishers in Lviv.

In view of the above, we may state that international book fairs are not only trading, educational, scientific and research platform for professionals, but also a part of the international cultural cooperation and important direction for the development of the interstate contacts and relations in general.

Professionals use such effective method as scientific, scientific and practical conferences, seminars, workshops, presentations, discussions, etc. in the study of current trends in the book market. At the present stage of the development of world book publishing and book distribution, participants of the book market realize that interrelation and interdependence have become the defining moments of their activity. And the role of exhibitions and fairs is enormous here. In the context of constant growth and expansion of the structure of the publishing repertoire, the emergence of new ones and the improvement of the old traditional marketing techniques, fairs and exhibitions more often become information exchanges and powerful mechanisms of book's advertising and propaganda, and therefore, the means of cultural development.

The world book culture appears as the unified component of national book cultures, each contributing to this unity in its unique way. The Ukrainian book business is not only an achievement of our country, but also a component of the world book process. Therefore, the promotion and popularisation of the Ukrainian culture at the national and world levels is impossible without the translation industry, which includes translation of the Ukrainian books into foreign languages and foreign into Ukrainian. Moreover, international book events usually attract the attention of society, public figures, media and give authors the opportunity to meet their readers. Thus, active participation of Ukraine in the international book fairs and exhibitions is an effective form of international cooperation, advertising of publishing houses and their products, establishment of professional contacts between all participants of the book market as a means of promoting the book and reading, as one of the channels 
of book distribution. International book fairs contribute to the integration of the Ukrainian book into the world book publishing process, acquaintance of the foreign readers with the Ukrainian authors, translators, illustrators and artists.

Nowadays, the translation of the literary text has a great significance in the literary process. In the European cultural tradition, there is a growing number of names of foreign authors, including Ukrainian, and a growing need for translations. We are observing an era of multilingualism, a dialogue of generations. Today, translation is one of the parts of the literary process. It is not the simple copying, not a craft but a kind of creative writing. Moreover, translation is one of the aspects of international cooperation, where the participation of the Ukrainian publishing houses is of great importance, because one of the functions of translation is to establish contacts between peoples, epochs and space, and that is why the accuracy of translation is very important and is impossible without an active participation of parties interested in the translation.

In 2018, contemporary Ukrainian literature in the world was presented by Serhii Zhadan's prose (he became a kind of record holder - 11 of his books have been translated), Tetiana Maliarchuk, Sofiia Andrukhovych, Andrii Liubka, Andrii Kurkov, Yurii Vynnychuk, Oksana Zabuzhko and others. The poetry of Serhii Zhadan, Yurii Andrukhovych, Liubov Yakymchuk, Halyna Kruk, Pavlo Korobchuk, Vano Kriuger can be found in Polish, Czech, English, Belarussian. As to the children's literature, the book "Loudly, Softly, in a Whisper" by Art Studio Agrafka was translated in Spain, Italy, South Korea, India, Catalonia and Taiwan. And the book "I see that" - in Italy, Slovakia, South Korea, France, Brazil, Portugal and India; Halyna Vdovychenko's book was translated into Chinese, etc. (Korniienko, 2018). The results of 2019 show that the translation of the Ukrainian books for adult population has been reduced compared to the previous year. The number of translations of children's books has increased.

Today, one of the means of cultural diplomacy and international cooperation for Ukraine is literary translation, that is why the Ukrainian Book Institute presented the programme Translate Ukraine at the Frankfurt Book fair. The main purpose and task of the programme is the intention to familiarize the foreign reader with the works of Ukrainian writers. Bohdan Neborak, head of the translation sector of the Ukrainian Book Institute, informed that "within the framework of the programme, foreign publishers can apply for translation grants and license. The maximum grant amount is 4,000 euros. It was also mentioned that this became possible due to the support of the Ministry of Culture, Youth and Sports and the Ministry of Finance" (Tanasiichuk, 2019). It should be noted that expenditures for the implementation of the programme of support for the translation of the Ukrainian author's works to other languages are 9.3 million hryvnias.

The Ukrainian publishing house "Nash Format" - is a good example that our country is ready to produce a high quality cultural product. It is known for its translations of western non-fiction bestsellers. From 2014 to 2016, the number of publications increased from 43 thousand to 194 thousand. According to the director of the publishing house Anton Martynov, five bestsellers over the last 7 years are: 
- "Atlas Shrugged" by Ayn Rand - 127,000 sold copies of three parts;

- "Henry Ford. My life and work" - 46,000 copies sold;

- "Why Nations Fail" by Daron Acemoglu and James A. Robinson - 34,000;

- "The Subtle Art of Not Giving a F*ck" by Mark Manson - 24,000;

- "The Miracle Morning: The Not-So-Obvious Secret Guaranteed to Transform Your Life" by Hal Elrod - 18,000 (Andreitsiv, 2019).

The first International Exchange Programme for Publishers developed by British Council and aimed at creating links between the UK publishing experts and publishers in other emerging markets deserves special mention. Experts from the UK, Ukraine, Georgia and Turkey have been involved in the project. It is already known that Mykola Kovalchuk (ArtHuss) and Kateryna Nosko (IST Publishing) became participants from Ukraine. Ukrainian fellowship holders will be able to visit their partners in the UK, look behind the scenes of the publishing sector and meet other experts. After completion of the exchange programme, its fellowship holders will be able to participate in a competition for professional development grants of up to 3,000 pounds each (Publishers Forum, 2019).

It is impossible to imagine the cooperation in the book publishing industry without the involvement of libraries. The involvement of the Ukrainian libraries in the international programmes and projects, strengthening of links in providing access to the documents on the basis of new information technologies, increasing the number of personal contacts have determined changes in the practical activity of libraries of all types. Moreover, according to V. Borysenkova (2018) "the library is becoming the main channel through which more and more representatives of different segments of the population join the process of cooperation, this is the place where the public consolidates on social issues, and, in our opinion, this is very important for the development of partnership, cooperation and formation of civil society". As Yu. Horban (2019), the scholar, accurately pointed out, "correctly chosen strategic directions of the library development determine the success of its activity in the long term. The balance of management approaches with the priority of the situational approach enables the library to respond quickly to changes in society, Ukrainian education and information requests of users, to meet the demands of the time. It is appropriate to maintain a balance between different areas of activity (introduction of modern information technologies in the work of the library, establishing communication with users, information support, and intensification of library's scientific and publishing work). A valuable resource of the library is its staff, whose task is to shape new views of the users on library activities. The use of modern information technologies in the library's work (electronic catalogue, library website, virtual help, book trailers, communication with users and libraries through social networks) has a positive impact on the image and the results of the institution's activities".

The foreign experience is used to ensure the interaction of the Ukrainian and world book processes, increase production and quality, improve working conditions of the employees of the industry. However, it should be noted that its use is impossible without a thorough and objective analysis. The implementation of national tasks to support the international cooperation should take 
place if proper domestic conditions are formed, namely: maximum interest of modern Ukrainian society in a book, preservation of the fundamental value of the book in the conditions of the spread of new information technologies; the proper intensity and quality of book business growth; establishing of a modern legal framework for book industry, etc.

\section{Conclusions}

Thus, international cooperation in book publishing industry intensifies our country's interstate relations; contributes to the strengthening of the international authority of Ukraine; serves as a statement of common to all values; promotes the development of the national book industry; attracts Ukrainians to the world's spiritual and social values, technological achievements; ensures a direct and proper exchange of cultural, intellectual and material values. Therefore, book publishing as a means of dissemination of national culture is at the same time a determining factor of progress of the world book industry and a phenomenon of international culture. An international interaction of cultures is needed for the development of each individual national culture, for the emergence of new resources and motivation for improvement. Thus, the necessity of international book publishing contacts depends on the objective needs.

The study identifies the main directions of international cooperation, including Ukraine's participation in the international book fairs, exhibitions; publishers' participation in the international programmes; intense activity in the field of literary translation, etc. Thereby, the strategic goal and priorities of the international cooperation of Ukraine in the book publishing industry have been defined: firstly, to increase the level of the national book publishing; secondly, the use of world achievements in domestic practice; thirdly, the promotion of the Ukrainian book publishing in the world.

\section{References}

Andreitsiv, I. (2019, November 7). Pereklasty svit ukrainskoiu: yak "Nash format" shukaie inozemni knyhy, shchob vydaty yikh v Ukraini [Translate the world into Ukrainian: How "Nash format" is searching for foreign books to publish them in Ukraine]. Ukrainska pravda. https://ife.pravda.com.ua/culture/2019/11/7/238832/ [in Ukrainian].

Antonyk, O. (2019). Knyzhkova kultura yak obiekt knyhoznavchoho dyskursu i mizhdystsyplinarnoho dialohu [Book culture as an object of literary discourse and interdisciplinary dialogue]. Bibliotechnyi visnyk, 1, 3-11. https://doi.org/ 10.15407/ bv2019.01.003 [in Ukrainian].

Borysenkova, V.V. (2018). Formy ta perspektyvy mizhnarodnoho spivrobitnytstva bibliotek [Forms and prospects of international cooperation of libraries]. Molodyi vchenyi, 11(2), 993-997 [in Ukrainian].

Demuz, I. O. (2018). Natsionalnyi knyzhkovyi rynok u konteksti realizatsii humanitarnoi derzhavnoi polityky [National book market in the context of the implementation 
of humanitarian public policy]. University economic bulletin, 37(1), 69-74. https:// doi.org/10.5281/zenodo.1220635 [in Ukrainian].

Horban, Yu. I. (2019). Rozvytok universytetskoi biblioteky: kompleks stratehichnykh rishen [University Library Development: A Complex of Strategic Solutions]. National Academy of Managerial Staff of Culture and Arts Herald, 2, 180-184. https:// doi.org/10.32461/2226-3209.2.2019.177426 [in Ukrainian].

Horobets, O. O. (2018). Statystychnyi analiz knyhovydannia v Ukraini ta sviti [Statistical analysis of book publishing in Ukraine and in the world]. Statistics of Ukraine, 2, 2229 [in Ukrainian].

Korniienko, N. (2018, December 25). Nashi za kordonom: inozemni pereklady ukrainskykh knyzhok 2018-ho [Our books abroad: foreign translations of Ukrainian books in 2018]. Chytomo. http://www.chytomo.com/nashi-za-kordonominozemni-pereklady-ukrainskykh-knyzhok-2018-ho/ [in Ukrainian].

Kravchenko, M. (2018a). Yakym buv pershyi krok Ukrainy na knyzhkovii vystavtsi v AbuDabi [What was the first step of Ukraine at the book exhibition in Abu Dhabi]. Ukrinform. https://www.ukrinform.ua/rubric-culture/2456744-ukraina-persijkrok-na-knizkovij-vistavci-v-abudabi.html [in Ukrainian].

Kravchenko, M. (2018b). Shcho dala Ukraini uchast u knyzhkovii vystavtsi u Shardzhi $\mathrm{v}$ OAE? [What did Ukraine get from participating in the book exhibition in Sharjah in the UAE?]. Ukrinform. https://www.ukrinform.ua/rubric-culture/2578900-sodala-ukraini-ucast-u-knizkovij-vistavci-u-sardzi-v-oae.html [in Ukrainian].

Publishers Forum. (2019, July 18). Mizhnarodna prohrama obminu dlia vydavtsiv - Nabir uchasnykiv vidkryto [International Publisher Exchange Program - Registration is open]. https://bookforum.ua/en/mizhnarodna-programa-obminu-dlya-vydavtsivnabir-uchasnykiv-vidkryto/ [in Ukrainian].

Tanasiichuk, O. (2019). Na Frankfurtskomu knyzhkovomu yarmarku prezentuvaly prohramu Translate Ukraine ["Translate Ukraine" program was presented at the Frankfurt Book Fair]. Ukrinform. https://www.ukrinform.ua/rubricculture/2801637-na-frankfurtskomu-knizkovomu-armarku-prezentuvaliprogramu-translate-ukraine.html [in Ukrainian].

Verkhovna Rada Ukrainy. (2003). Pro derzhavnu pidtrymku knyhovydavnychoi spravy v Ukraini [On State Support for Book Publishing in Ukraine]. https://zakon.rada. gov.ua/laws/show/601-15 [in Ukrainian].

Vydavnytstvo Staroho Leva. (2017, December 14). Ukraina vidvidala mizhnarodnyi knyzhkovyi yarmarok Beirut International Arab Book Fair u Livani [Ukraine took part in the Beirut International Arab Book Fair in Lebanon]. https://starylev.com. ua/news/ukrayina-mizhnarodnyy-knyzhkovyy-yarmarok-beirut-internationalarab-book-fair-u [in Ukrainian]. 


\title{
МІЖНАРОДНЕ СПІВРОБІТНИЦТВО УКРАЇНИ У КНИГОВИДАВНИЧІЙ ГАЛУЗІ
}

\author{
Каракоз Олена Олександрівна
}

Кандидат історичних наук, доцент, ORCID:0000-0002-7772-1530,karakoc@ukr.net, Київський національний університет культури і мистецтв, Київ, Україна

Мета дослідження полягає в аналізі програм міжнародного співробітництва у сфері книговидавничої справи та визначення перспективних напрямків у галузі української книжкової справи для її розвитку в процесі такого співробітництва.

Методологія дослідження базується на використанні порівняльно-історичного та статистичного методів, які дали можливість отримати всебічну інформацію у сфері міжнародного співробітництва в галузі українського книговидання як діяльності, що має важливе значення для культурного та інтелектуального розвитку суспільства. Книгознавчі методи - функціональний, аналітико-тематичний, структурно-типологічний - дали можливість визначити форми та методи поширення співробітництва в галузі книжкової справи й одночасно з'ясувати перспективи розвитку вітчизняного книговидання, книгорозповсюдження й книговикористання.

Наукова новизна полягає в тому, що вперше комплексно досліджено чинні програми міжнародних зв'язків у книговидавничій галузі. Галузь міжнародного співробітництва в книжковій справі проаналізовано як складний системний об’єкт, що реалізує свої функції в різних аспектах та на різних рівнях. Отже, міжнародне співробітництво як засіб розповсюдження національної культури водночас $є$ визначальним чинником прогресу світової книжності та феноменом інтернаціональної культури. А для розвитку кожної окремої національної культури та появи нових ресурсів, стимулів вдосконалення потрібна міжнародна взаємодія культур. Тому необхідність міжнародних книжкових контактів зумовлена об’єктивними потребами.

Висновки. Доведено, що міжнародне співробітництво в галузі книжкової справи має на меті активізацію міждержавних відносин України 3 іншими країнами; сприяє закріпленню міжнародного авторитету України; слугує ствердженням загальнолюдських цінностей; сприяє розвитку національної книжкової справи; залучає українців до загальносвітових духовних та соціальних цінностей і науково-технічних досягнень; забезпечує прямий та рівноправний обмін культурними, інтелектуальними і матеріальними цінностями.

Виявлено основні напрями міжнародного співробітництва, головними з яких є участь України на міжнародних книжкових ярмарках, виставках; участь видавців у міжнародних програмах; активна діяльність у галузі перекладу літератури та ін. Таким чином, визначено стратегічну мету та пріоритетні завдання міжнародного співробітництва України в галузі книжкової справи: по-перше, підвищення рівня національної книжкової справи; по-друге, використання світових досягнень у національній практиці; по-третє, популяризація українських здобутків книговидання у світовому просторі.

Ключові слова: міжнародне співробітництво; книговидання; культура; українська книга. 


\title{
МЕЖДУНАРОДНОЕ СОТРУДНИЧЕСТВО УКРАИНЫ В КНИГОИЗДАТЕЛЬСКОЙ ОТРАСЛИ
}

\author{
Каракоз Елена Александровна
}

Кандидат исторических наук, доцент, ORCID:0000-0002-7772-1530,karakoc@ukr.net, Киевский национальный университет культуры и искусств, Киев, Украина

Цель исследования заключается в анализе программ международного сотрудничества в сфере книгоиздания и определения перспективных направлений в области украинского книжного дела для его развития в процессе такого сотрудничества.

Методология исследования базируется на использовании сравнительноисторического и статистического методов, которые позволили получить всестороннюю информацию в сфере международного сотрудничества в области украинского книгоиздания как деятельности, имеющей важное значение для культурного и интеллектуального развития общества. Книговедческие методы - функциональный, аналитико-тематический, структурно-типологический - позволили определить формы и методы распространения сотрудничества в области книжного дела и одновременно выяснить перспективы развития отечественного книгоиздания, книгораспространения и книгоиспользования.

Научная новизна заключается в том, что впервые комплексно исследованы действующие программы международных связей в книгоиздательской отрасли. Отрасль международного сотрудничества в книжном деле проанализирована как сложный системный объект, реализующий свои функции в различных аспектах и на разных уровнях. Итак, международное сотрудничество как средство распространения национальной культуры одновременно является определяющим фактором прогресса мировой книжности и феноменом международной культуры. А для развития каждой отдельной национальной культуры и появления новых ресурсов, стимулов совершенствования необходимо международное взаимодействие культур. Поэтому необходимость международных книжных контактов обусловлена объективными потребностями.

Выводы. Доказано, что целью международного сотрудничества в области книжного дела является активизация межгосударственных отношений Украины с другими странами; оно способствует закреплению международного авторитета Украины; служит утверждению общечеловеческих ценностей; способствует развитию национального книжного дела; привлекает украинцев к общемировым духовным и социальным ценностям и научно-техническим достижениям; обеспечивает прямой и равноправный обмен культурными, интеллектуальными и материальными ценностями.

Выявлены основные направления международного сотрудничества, главными из которых являются участие Украины в международных книжных ярмарках, выставках; участие издателей в международных программах; активная деятельность в области перевода литературы и др. Таким образом, определена стратегическая цель и приоритетные задачи международного сотрудничества Украины в области книжного дела: во-первых, повышение уровня национального книжного дела; во- 
ISSN 2410-1915 (Print) • Culture and Arts in the Modern World. Issue 21 • ISSN 2616-423X (Online)

вторых, использование мировых достижений в национальной практике; в-третьих, популяризация украинских достижений книгоиздания в мировом пространстве.

Ключевые слова: международное сотрудничество; книгоиздание; культура; украинская книга. 